\title{
Reconciling \\ Anti-Essentialism and Quantitative Methodology
}

\section{By Mathias FjÆLlegaARd Jensen}

\begin{abstract}
Quantitative methodology has a contested role in feminist scholarship which remains almost exclusively qualitative. Considering Irigaray's notion of mimicry, Spivak's strategic essentialism, and Butler's contingent foundations, the essentialising implications of quantitative methodology may prove less problematic if research projects assert strategic or political feminist aims. Still, a feminist deconstructive argument can be formed against quantitative studies in which socially constructed categories are considered independently determined. However, by application of Williams' ideas of treating the categories in question as dependently rather than independently determined, social categories can be deconstructed quantitatively, enriching both the theoretical and empirical understandings of population-level social constructions of genders, ethnicities etc. Quantitative deconstruction has the potential to reconcile anti-essentialism and quantitative methodology, and thus, to make peace in the quantitative/qualitative Paradigm Wars.
\end{abstract}

\section{KEYWORDS}

Essentialism, quantitative, qualitative, feminism, gender, deconstruction, methodology

As a PhD fellow at the Department of Economics, CBS, Mathias Fjællegaard Jensen researches gendered consequences of technological change. Before commencing his PhD, Mathias studied economics and gender studies at the University of Cambridge. 


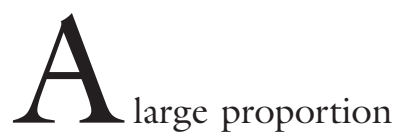

of gender research now actively engages with quantitative methodology, especially in the US, but explicitly feminist research remains almost exclusively qualitatitive (Cohen et al. 2011). Despite frequent feminist promotions of quantitative methodology (e.g. Jayaratne \& Stewart 1991; Oakley 1998, 2000), the Paradigm Wars are still being fought; feminism and quantitative methodology are yet to be united in general practice.

Feminist theorists have argued that quantitative methods are androcentric and have been created to support patriarchal social structures (Harding 1986; Jayaratne \& Stewart 1991). Furthermore, feminists recognise that the experiences of a woman or indeed, of any individual - cannot be captured by numbers without essentialising the identities of the researched subjects. The essentialising implications of categorisation and of a binary gender variable in quantitative research directly conflict with feminist theories of deconstruction. On the other hand, it is hard to argue against the application of quantitative methods in the interests of uncovering and providing evidence of gender discrimination - for example, studies of population-level wage inequalities - even though these inequalities are socially constructed (Cohen et al. 2011). Consequently, feminist resistance to the application of quantitative methods has provoked other social scientists undertaking gender research:

Perhaps somewhat polemically, we argue that gender studies pose a particular challenge to the quest of raising quantitative methodological standards. In part, this is because, in the earlier phase of feminist writing, qualitative methods were often seen as preferable to quantitative approaches. It is also the case that some social scientists lack confidence in numerical skills and have a fear of statistics (Scott 2010: 226).
Unfortunately, existing feminist promotions of quantitative methodologies have not succeeded; feminist research continues to be almost exclusively qualitatitive (Cohen et al. 2011). At the same time, non-feminist scholars widely engage in quantitative research on women, but from a feminist perspective, "[i]t is hard to watch researchers without feminist training do research on women and without concern for its impact on women or on feminism" (Williams 2012: 84). In the interests of facilitating explicitly feminist applications of quantitative methods, I aim to recover a distinctively feminist approach to quantitative methodology by reconciling anti-essentialism and quantitative methodology. I attempt to show that research questions that require the application of quantitative methods can also be answered from a feminist perspective.

This article is structured into four sections, followed by concluding remarks. The first section briefly outlines feminist arguments against quantitative methodology, as well as existing feminist promotions of quantitative methodology. In the second section, I discuss how standard applications of quantitative methods in the social sciences unavoidably involve essentialising individuals through categorisation. In the third section, feminist theory is revisited in order to provide a discussion of essentialism, anti-essentialism, and deconstruction in the context of quantitative methodology. In the final section, I suggest that a distinctively feminist approach to quantitative methodology can be recovered by reconciling anti-essentialism and quantitative methodology through a process of quantitative deconstruction of social categories.

\section{The Paradigm Wars}

First, the background to the discussion of anti-essentialism and quantitative methodology is briefly outlined, paying particular 
attention to the so-called Paradigm Wars and to suggested ways of making peace in these wars. Toby E. Jayaratne and Abigail J. Stewart (1991), and Ann Oakley (1998, 2000) reviewed the arguments for and against applications of quantitative methods in feminist research, highlighting how "the early feminist methodology texts all celebrated qualitative methods as best suited to the project of hearing women's accounts of their experiences" (Oakley 1998: 708, my emphasis). From a feminist perspective, traditional scientific methods, and particularly quantitative methods, were seen as regressive, sexist, and androcentric (e.g. Gilligan 1982; Harding 1986). Stemming from these feminist reservations about the application of positivist, quantitative methods, and from the celebration of qualitative methods in feminist scholarship, the 'paradigm argument' arose - that is, the argument that qualitative and quantitative methodologies represent two different and incompatible paradigms in the social sciences. Oakley (1998) characterized the established feminist resistance to quantitative methodology by means of her notion of the 'three p's':

Underlying the various arguments in the feminist case against quantitative methods are three fundamental objections: the case against positivism; the case against power; and the case against $p$ values, or against the use of statistical techniques as a means of establishing the validity of research findings (Oakley 1998: 709-710, emphasis in the original).

Positivism is dangerous since research outcomes are presented as objective facts, but in feminism, traditional “'Objectivity' is reframed as 'male subjectivity"' (Oakley 1998: 710). Power refers to the conventional hierarchical relationship between the researcher and the researched. From a feminist perspective, this exploitative relationship itself makes research findings invalid. $P$ values refer to tests for statistical significance in quantitative research. Reducing the significance of studied subjects and their experiences to a single number is also problematic from a feminist perspective (Oakley 1998).

After outlining the background of the Paradigm Wars, Jayaratne and Stewart (1991), and Oakley (1998, 2000) also proposed ways to make peace by suggesting research strategies that directly target the feminist criticisms of quantitative methodology. Three of the proposed research strategies relate directly to the topic of this article.

First, they recommended choosing research methods after deciding on a research question, hence selecting the best methods to address the problem in question. Jacqueline Scott (2010) also supported the view that one should not talk about a superior methodology, but rather consider the methodology that best fits one's research question. Ask a question and subsequently apply the methods that can optimally answer it.

Secondly, researchers should leave behind the dichotomy between quantitative and qualitative methodologies, and apply mixed methods and triangulation when appropriate. The social sciences have the potential to challenge the standard, singlemethodology approach, and to combine the strengths of theoretical, qualitative, and quantitative methodologies - 'triangulation' could improve the validity and robustness of research outcomes (Hughes \& Cohen 2010). Triangulation appeared as a way to find peace in the "war-of-words" about applied methods (Scott 2010: 223), and Scott (2010: 235) highlighted how "qualitative research can help inform the way that quantitative researchers (some of whom are feminists) interpret what they count."

Thirdly, the applied methods should always be questioned and justified directly by researchers in their published work. Methodological reflections are at the centre of feminist theory, and strengthening the focus on methodological reflections in quantitative research could target the feminist criticisms of quantitative methodology itself. 
These three research strategies could potentially challenge the qualitative/quantitative dichotomy and facilitate feminist applications of quantitative methods. However, Scott notes that:

Some readers will remain unconvinced that quantitative research can help feminist inquiry. They will insist that women's experiences cannot be reduced to numbers. No serious social scientist would claim that they could be (Scott 2010: 234).

Even if no social scientist would claim that individuals' experiences can be reduced to numbers, this is what quantitative methodology does: individuals become rows and columns in a spreadsheet. As a result:

Articles written from an explicitly feminist perspective or with feminist or transformative methodological justifications very rarely employ quantification. There is, therefore, little here to suggest that feminists use quantitative methods (Cohen et al. 2011: 581-582).

Thus, the qualitative/quantitative dichotomy persists in general feminist practice, and the promotions of quantitative methodology put forward by Jayaratne and Stewart (1991), and Oakley $(1998,2000)$ have not succeeded in uniting feminism and quantitative methodology.

The following section explores further how quantitative methodology essentialises individuals and their identities, before moving on to a theoretical discussion of the implications of essentialism. The discussion of essentialism makes it possible to suggest a distinctively feminist approach to quantitative methodology, and hence again challenge the qualitative/quantitative dichotomy.

\section{Quantitative Methodology ESSENTIALISES}

Quantitative methodology relies on coded categories, categorical variables. In the con- text of this articl, the most obvious categorical variable is the gender or sex variable, which is normally treated as a given, independent variable, and not as a dependent variable. ${ }^{1}$ Already here, a feminist issue arises: quantitative researchers often do not distinguish between gender and sex (Williams 2010). Judith Butler (1992: 17) branded this form of categorisation and discourse of sex 'material violence'. Nevertheless, the gender/sex variable is coded: 0 for men, 1 for women. Almost all quantitative studies examining gender build on this dichotomous, binary gender variable, again conflicting with deconstructive developments within feminist thought, which reject the gender binary.

In statistical multivariate modelling, intersectionality is introduced by adding more categorical variables: one each for ethnicity, religion, disability etc. (e.g. Metcalf 2009). Many datasets come with variables at different levels of detail. For example, the UK Labour Force Survey, which provides quarterly datasets describing the UK labour market, includes several categorical variables for ethnicity, providing a range of 7 to 18 ethnic subcategories (Office for National Statistics 2014). Thus, the quantitative researcher is left with a choice - not necessarily an objective choice - between including more subcategories, risking statistically insignificant results due to smaller sample sizes, or including fewer subcategories, thus losing the diversity and detail the dataset actually provides. In other words, the researcher chooses how much to reduce or essentialise the identity of the studied subjects, and hence also chooses which axes of power to (un)cover (Cho et al. 2013).

When individuals are categorised to provide a numerical dataset, the statistician sacrifices variability in the lived experience of their researched subjects - the identities of the subjects are essentialised. Much feminist theory reflects on the topic of essentialism, and Ellen Rooney pointed out that: 
Feminisms return to the problem of essentialism - despite their shared distaste for the mystifications of Woman - because it remains difficult to engage in feminist analysis and politics if not 'as a woman' (Spivak \& Rooney 1993: 2).

In order to reconcile feminist anti-essentialism and quantitative methodology, this dissension between the theoretical and political aspects of feminisms is crucial to understand. Therefore, the next section revisits feminist theory and provides a discussion of essentialism, anti-essentialism, and deconstruction in the context of quantitative methodology.

\section{EssEnTIALISM, ANTI-EssENTIALISM, AND DECONSTRUCTION}

Essentialism and anti-essentialism have been central themes in feminist literature for decades. However, in a 1984 interview with Elizabeth Gross, Gayatri Chakravorty Spivak reignited the debate when introducing her idea of strategic essentialism in the context of clitoridectomy and the formation of a feminist practice and discourse:

I think we have to choose again strategically, not universal discourse but essentialist discourse. I think that since as a deconstructivist, - see, I just took a label upon myself I cannot in fact clean my hands and say I'm specific. In fact I must say I am an essentialist from time to time (Spivak 1985: 183).

Spivak found strategic essentialism applicable not only in feminist and women's discourses, but also in the context of her analysis of the work by the Subaltern Studies Group. Here, Spivak again applied the concept of strategic essentialism and elaborates on its implications for the studied subject:

(...) I would suggest that elements in their text would warrant a reading of the project to retrieve the subaltern consciousness as the attempt to undo a massive historiographic metalepsis and "situate" the effect of the subject as subaltern. I would read it, then, as a strategic use of positivist essentialism in a scrupulously visible political interest (...) This would allow them to use the critical force of anti-humanism, in other words, even as they share its constitutive paradox: that the essentializing moment, the object of their criticism, is irreducible (Spivak 1987: 205, emphasis in the original).

Speaking as a deconstructionist, Spivak's promotion of this strategic form of essentialism received a lot of attention, but mainly because of its essentialising element. Spivak's work on French philosophy was reflected in her statements about essentialism. Not only had Derrida been a topic of much of her research, but she also found inspiration in Lucy Irigaray's writing. Despite the often essentialist reading of Irigaray's work, her notion of mimicry also proved important for the role of strategic essentialism. In this context, Spivak challenged her readers and asked "Why do we become essentialist readers when we read someone like Irigaray?" (Spivak \& Rooney 1993: 17). Spivak encouraged us to read Irigaray within the tradition of French writing in which she was situated. In her essay, The Power of Discourse and the Subordination of the Feminine, Irigaray summed up her ideas of mimicry as a tool for feminism:

To play with mimesis is thus, for a woman, to try to recover the place of her exploitation by discourse, without allowing herself to be simply reduced to it. It means to resubmit herself - inasmuch as she is on the side of the 'perceptible', of 'matter' - to 'ideas', in particular to ideas about herself, that are elaborated in/by a masculine logic, but so as to make 'visible', by an effect of playful repetition, what was supposed to remain invisible: the cover-up of a possible operation of the feminine in language. It also means 'to unveil' the 
fact that, if women are such good mimics, it is because they are not simply resorbed in this function (Irigaray 1991: 124).

Irigaray's encouragement to apply mimesis, however, did not mean that women should adopt the patriarchal discourse and thereby define women relative to men. Nevertheless, it did imply that women could use a male discourse, such as a quantitative one, to "recover the place of her exploitation" (Irigaray 1991: 124). Still, Irigaray maintained that women's movements often challenged only the distribution of power, not the power structure itself, thereby again subjecting themselves to the phallocratic order (Irigaray 1991: 128). Again, a tension between theoretical and strategical arguments arose - the aim was to challenge the phallic order, but the practical tool, mimesis, would do so from within this order. Whitford pointed out how Irigaray's work developed over time:

The direction her work is taking involves a more direct focus on women's civil status, their position as a sex before the law, the need for womankind to be recognized as a genre distinct from mankind, and the importance of translating sexual difference into specific social forms, both to mediate relations between women themselves, and also to lay claim to an existence embodied in distinct and concrete instances as a basis for relationships with and negotiations with the world of men (Whitford 1991: 10, emphasis in the original).

The essentialist aspect of Irigaray's work arose as she wrote from a perspective of difference, claiming a space for womankind and mankind respectively. Deconstructionists would, as Spivak and Butler do, see both 'kinds' as a product of social interactions and constructions. At the same time, however, according to Butler, Irigaray argued that "women constitute a paradox, if not a contradiction, within the discourse of identity itself. Women are the 'sex' which is not 'one.' Within a language pervasively masculinist, a phallogocentric language, women constitute the unrepresentable" (Butler 2006: 13, emphasis in the original). Perhaps, then, Irigaray essentialised less than is often assumed. In fact, Xu (1995) found that the controversy over Irigaray's essentialism arose when the strategic aspect of her application of mimicry was disregarded.

After the publication of Gender Trouble in 1990, Butler also entered the discussion about the notion of 'women' as a political category in 1991 with the first version of her article on Contingent Foundations. In 1992, the final version appeared as part of the collection Feminists Theorize the Political, which Butler and Joan W. Scott edited together. Already in the introduction, together they targeted the interaction, or rather the tension, between the theoretical and the strategic:

To perform a feminist deconstruction of some of the primary terms of political discourse is in no sense to censor their usage, negate them, or to announce their anachronicity. On the contrary, this kind of analysis requires that these terms be reused and rethought, exposed as strategic instruments and effects, and subjected to a critical reinscription and redeployment (Butler \& Scott 1992: xiv, emphasis in the original).

Butler's own contribution to the collection explored this relationship further, and like Spivak, she found a place for a strategic or political use of categorical terms:

To deconstruct the concept of matter or that of bodies is not to negate or refuse either term. To deconstruct these terms means, rather, to continue to use them, to repeat them, to repeat them subversively, and to displace them from the contexts in which they have been deployed as instruments of oppressive power (Butler 1992: 17) 
Butler admitted that categories such as 'women' and 'men' could be used, but only subversively. In Bodies That Matter, Butler elaborated on the difference between a term's metaphysical presence and the political aims it could serve: by re-examining a certain term, one could "free it from its metaphysical lodgings (...) to permit the term to occupy and serve very different political aims" (Butler 1993: 30). From this statement, it follows that a researcher can indeed apply categorical terminology, even from Butler's deconstructive point of view, but subversion is the prerequisite for its application.

Now, it is interesting to consider the binary gender variable denoting 'women' and 'men'. They are categories and terms that have indeed been employed by oppressive powers, but if these categories themselves can be used to prove this oppression and the implied power relations, is that not to use them subversively, as Butler proposed? They would then serve a clearly feminist political aim. The categorical discourse, however, can remain oppressive if one is not careful to address the 'metaphysical lodgings' of terms (Butler 1993: 50), which is often neglected by quantitative researchers. Nevertheless, Butler further acknowledged that a foundationalist move:

\section{(...) can be used as a part of such a radical} agenda. Note that I have said, 'it can be used': I think there are no necessary political consequences for such a theory, but only a possible political deployment (Butler 1992: 8).

Still, this should not be seen as unconditional support for Spivak's strategic essentialism, and especially not of essentialism itself. Indeed, in Gender Trouble, Butler shifted the focus from the need of categories for a political agenda: "Instead, we ought to ask what political possibilities are the consequence of a radical critique of the categories of identity" (Butler 2006: xxxii). Later, Butler concluded that feminist theo- ry had agreed that an essentialist category, 'women', was no longer useful in unifying the diverse lives and experiences of those who could be defined as women (Butler et al. 2004: 336).

Spivak and Butler did not predict the consequences of their promotion of strategic essentialism and foundationalist moves in the name of feminist political aims. Indeed, Spivak later reconsidered her call for strategic essentialism because her readers tended to focus on 'essentialism' and forgot about the 'strategic' (Spivak \& Rooney 1993: 5). Therefore, she withdrew her support of the term because of its misuse, rather than because she gave up on it or the project itself (Danius et al. 1993). As Spivak explained, "my notion just simply became the union ticket for essentialism" (Danius et al. 1993: 35), and it was never her intention to provide such a ticket. Similarly, Butler realised that strategy should not be the only consideration to make when applying certain categorical terms in a political context. She emphasised that the semantic meaning of a term "travels through discourse" in ways that authors cannot predict (Butler et al. 2004: 331). Hence, one must consider the ontological development of categorical terms. Butler concluded her thoughts on the strategic or political uses of essentialist terms by reflecting on her ideas from Bodies That Matter: "So, I guess I would be a little less optimistic about the possibility of a radical unmooring than I was in 1993" (Butler et al. 2004: 331). Radical unmooring was sacrificed because of the unintended implications of essentialist terminology and categorisation, and the place for quantitative methodology in feminist research remains unclear. However, the next section will show that deconstruction of social categories and the analysis of discourse are not necessarily incompatible with quantitative methodology. 


\section{Quantitative Deconstruction}

Within the disciplines of linguistics and sociolinguistics, discourse analysis has enabled the deconstruction of essentialist terminology, social categories, and their implications (Lazaraton 2002). Discourse analysis can even be performed quantitatively by codifying transcribed discourse, although this application of quantitative methods has also been contested (e.g. Schegloff 1993). Still, it remains difficult to apply the deconstructive principles of discourse analysis in certain areas of the social sciences, for example, in economic studies of populationlevel wage inequalities.

Thus, the question remains: How can the use of a binary gender variable be compatible with a deconstructive feminist project if strategy is not enough to secure compatibility? To answer this question, the ideas of sociologist and demographist Jill R. Williams (2010) provide valuable insights. Demographers have traditionally claimed to be scientific; they have argued to remain objective in their research (Williams 2010). However, as feminists have long realised, such positivist objectivity is impossible to retain, independently of the choice of method. Therefore, Williams (2010) proposed several feminist changes to the discourse in demographic research, but even more interestingly, she also suggested a method for examining the social constructions of genders quantitatively, that is, by treating gender as a dependent variable. Analysing gender as a dependent variable would enable the quantitative researcher to determine which social constructions that make up genders, contrasting traditional quantitative research which takes gender as given. Williams (2010: 205) explained:

An important point here is that because gender is an essential dependent variable, demographic research should study how demographic processes influence gendered process$\mathrm{es}$, including gender inequality.
Going from treating gender as an independent variable to treating it as a dependent variable would have important implications: researchers would no longer take gender as something independently, or indeed naturally given, but would rather view the categories 'women' and 'men' as constructions of all the other variables that datasets provide for their analysis. In other words, genders can also be deconstructed quantitatively, not only discursively.

Quantitative deconstruction of social categories could yield important insights into the population-level social constructions of genders, ethnicities etc. By reapplying deconstructive principles from discourse analysis, quantitative deconstruction could supplement the theoretical and empirical understandings of categorical variables and of the underlying identities of the researched subjects. Quantitative deconstruction has the potential to reconcile anti-essentialism and quantitative methodology and to join anticategorical and intercategorical approaches to intersectionality (McCall 2005). Hence, a distinctively feminist approach to quantitative methodology exists, and it can even be applied to promote a deconstructive feminist project.

\section{CONCLUSIONS}

From a theoretical perspective, quantitative methodology is problematic not only because of its patriarchal origins, but also because of its essentialising implications. However, Oakley (1998: 725) pointed out that a feminist rejection of quantitative methodology is itself essentialising:

The case against quantitative ways of knowing is based on a rejection of reason and science as masculine and an embracing of experience as feminine; but this is essentialist thinking which buys into the very paradox that it protests about.

Essentialism, therefore, is a challenge for 
feminist researchers that should be tackled by leaving the quantitative/qualitative Paradigm Wars behind, rather than by opposing quantitative methodology.

Also in feminist research, it is now clear that there is no such thing as the 'best method', but rather the methods that fit a research question most aptly. The quantitative/qualitative dichotomy should be left behind to open the way for mixed methods and triangulation, which could improve the validity of feminist research. Feminists are encouraged to acknowledge that

Quantitative researchers are not naïve positivists. They acknowledge the role of social construction in measures and are wary of quantification being seen as the equivalent of scientific reasoning. They know better than most that 'statistics can lie' (Scott 2010: 223).

Indeed, one cannot always rely on quantitative methods. However, methodological shortcomings are not unique to statistics, but rather to all poor research designs (Scott 2010). Depending on the research question, one way to improve the validity and robustness of research findings is through triangulation and the application of mixed methods.

The discussion of Irigaray's notion of mimicry, Spivak's strategic essentialism and Butler's contingent foundations has shown that the essentialising implications of quantitative methodology are less problematic if research projects keep a central strategic or political feminist aim. Even though "It is hard for the dogmatic philosopher to grasp that a strategist is a trickster, since there is no free play" (Spivak 1996: 159), a feminist deconstructive argument is easily formed against quantitative studies in which variables describing social constructs are considered to be independently determined variables. However, Williams' (2010) suggestion that the variables in question should be treated as dependent rather than independent makes it possible to deconstruct social categories quantitatively and to pro- vide important insights into population-level social constructions of genders, ethnicities etc. Such a methodological approach could enrich both the theoretical and empirical understandings of categorical variables and of researched subjects' underlying identities. Thus, quantitative deconstruction has the potential to reconcile anti-essentialism and quantitative methodology.

Feminist research is crucial for pointing out discrimination and inequalities, and at the population level, quantitative methodology provides powerful tools for doing so. Therefore, I encourage feminist researchers to step outside the qualitative paradigm and embrace the research questions for which quantitative methods open the way. At the same time, I encourage quantitative researchers to embrace feminist theory and consider its theoretical insights when doing research on gender and women. In the political and academic battle against gender discrimination, feminism has a key role to play, also in quantitative studies with potentially essentialising elements. As Spivak (1993: 18) pointed out: "There is no time for essence/anti-essence. There is so much work to be done."

In this article, I have demonstrated how the Paradigm Wars may finally be left behind if: 1) triangulation and mixed methods are applied when appropriate; 2) researchers analyse categorical variables strategically and subversively; and 3 ) antiessentialism and quantitative methodology are reconciled through a process of quantitative deconstruction.

\section{Notes}

1. The Cambridge Dictionary of Statistics defines a dependent variable as follows (Everitt 2006: 342): "The variable of primary importance in investigations since the major objective is usually to study the effects of treatment and/or other explanatory[/independent] variables on this variable and to provide suitable models for the relationship between it and the explanatory[/independent] variables." 


\section{REFERENCES}

- Butler, Judith (1992): Contingent Foundations: Feminism and the Question of "Postmodernism," in: Judith Butler \& Joan W. Scott (eds.): Feminists Theorize the Political. Routledge, New York.

- Butler, Judith (1993): Bodies That Matter: On the Discursive Limits of "Sex." Routledge, New York.

- Butler, Judith (2006): Gender Trouble: Feminism and the Subversion of Identity. Routledge, New York. - Butler, Judith; Olson, Gary A. \& Worsham, Lynn (2004): Changing the Subject: Judith Butler's Politics of Radical Resignification, in: Sara Salih \& Judith Butler (eds.): The Judith Butler Reader. Blackwell, Malden, MA.

- Butler, Judith \& Scott, Joan W. (1992): Introduction, in: Judith Butler \& Joan W. Scott (eds.): Feminists Theorize the Political. Routledge, New York.

. Cho, Sumi; Crenshaw, Kimberle \& McCall, Leslie (2013): Toward a Field of Intersectionality Studies: Theory, Applcations and Praxis, in: Signs: Journal of Women in Culture and Society $2015 / 38(4)$.

. Cohen, Rachel L.; Hughes, Christina \& Lampard, Richard (2011): The Methodological Impact of Feminism: A Troubling Issue for Sociology?, in: Sociology 2011/45(4).

- Danius, Sara; Jonsson, Stefan \& Spivak, Gayatri C. (1993): An Interview with Gayatri Chakravorty Spivak, in: Boundary 2 1993/20(2).

- Everitt, Brian S. (2006): The Cambridge Dictionary of Statistics. Cambridge University Press, Cambridge.

- Gilligan, Carol (1982): In a Different Voice. Harvard University Press, Cambridge, MA.

. Harding, Sandra G. (1986): The Science Question in Feminism. Cornell University Press, Ithaca. - Hughes, Christina \& Cohen, Rachel L. (2010): Feminists Really do Count: The Complexity of Feminist Methodologies, in: International Journal of Social Research Methodology 2010/13(3).

- Irigaray, Luce (1991): The Power of Discourse and the Subordination of the Feminine, in: Margaret Whitford (ed.): The Irigary Reader. Basil Blackwell, Cambridge, MA.

- Jayaratne, Toby Epstein \& Stewart, Abigail J. (1991): Quantitative and Qualitative Methods in the Social Sciences: Current Feminist Issues and Practical Strategies, in: M.M. Fonow \& J.A. Cook (eds.): Beyond Methodology: Feminist Scholarship as Lived Research. Indiana University Press, Bloomington.

- Lazaraton, Anne (2002): Quantitative And Qualitative Approaches To Discourse Analysis, in: $A n$ nual Review of Applied Linguistics 2002/22.
- McCall, Leslie. (2005): The Complexity of Intersectionality, in: Signs: Journal of Women in Culture and Society, 2005/30(3).

- Metcalf, Hilary (2009): Pay Gaps Across the Equality Strands: A Review. EHRC Research Report No. 14. Equality and Human Rights Commission, Manchester.

- Oakley, Ann (1998): Gender, Methodology and People's Ways of Knowing: Some Problems with Feminism and the Paradigm Debate in Social Science, in: Sociology 1998/32(4).

- Oakley, Ann (2000): Experiments in Knowing: Gender and Method in the Social Sciences. Polity Press, Cambridge.

- Office for National Statistics (2014): Volume 3: Details of LFS variables, in: Labour Force Survey User Guide.

- Schegloff, Emanuel A. (1993): Reflections on Quantification in the Study of Conversation, in: Research on Language and Social Interaction 1993/26(1).

- Scott, Jacqueline (2010): Quantitative Methods and Gender Inequalities, in: International Journal of Social Research Methodology 2010/13(3).

- Spivak, Gayatri C. (1985): Criticism, Feminism and the Institution: An Interview with Gayatri Chakravorty Spivak, in: Thesis Eleven 1985/10ll(l).

- Spivak, Gayatri C. (1987): Subaltern Studies: Deconstructing Historiography, in: In Other Worlds:

Essays In Cultural Politics. Methuen, New York. - Spivak, Gayatri C. (1996): More on

Power/Knowledge, in: Donna Landry \& Gerald M. MacLean (eds.): The Spivak Reader: Selected Works of Gayatri Chakravorty Spivak. Routledge, London.

- Spivak, Gayatri C. \& Rooney, Ellen (1993): In a Word: Interview, in: Gayatri Chakravorty Spivak (ed.): Outside in the Teaching Machine. Routledge, New York.

- Whitford, Margaret (1991): Introduction, in: Margaret Whitford (ed.): The Irigary Reader.

Routledge, Cambridge, MA.

-Williams, Jill R. (2010): Doing Feminist Demography, in: International Journal of Social Research Methodology 2010/13(3).

· Williams, Jill R. (2012): Caught between a Rock and a Hard Place: The Title IX Generation, Mathematics, and the State of Feminist Quantitative Social Science Research, in: Journal of Feminist Scholarship 2012/3.

- Xu, Ping (1995): Irigaray's Mimicry and the Problem of Essentialism, in: Hypatia 1995/10(4). 